Mountain JL, Hebert JM, Bhattacharyya PA, Underhill PA, Ottolenghi C, Gadgil M, Cavalli-Sforza LL (1995) Demographic history of India and mtDNA-sequence diversity. Am J Hum Genet 56:979-992

Rogers AR (1995) Genetic evidence for a Pleistocene population explosion. Evolution 49:608-615

Rogers AR, Fraley AE, Bamshad MJ, Watkins WS, Jorde LB (1996) Mitochondrial mismatch analysis is insensitive to the mutational process. Mol Biol Evol 13:895-902

Rogers AR, Harpending H (1992) Population growth makes waves in the distribution of pairwise differences. Mol Biol Evol 9:552-569

Sherry ST, Rogers AR, Harpending H, Soodyall H, Jenkins $\mathrm{T}$, Stoneking M (1994) Mismatch distributions of mtDNA reveal recent human population expansions. Hum Biol 66: $761-775$

Smith BD (1994) The emergence of agriculture. Scientific American Library, New York

Soodyall H (1993) Mitochondrial DNA polymorphisms in Southern African populations. $\mathrm{PhD}$ thesis, University of the Witwatersrand, Johannesburg

Soodyall H, Vigilant L, Hill AV, Stoneking M, Jenkins T (1996) mtDNA control-region sequence variation suggests multiple independent origins of an "Asian-specific" 9-bp deletion in sub-Saharan Africans. Am J Hum Genet 58:595608

Tamura K, Nei M (1993) Estimation of the number of nucleotide substitutions in the control region of mitochondrial DNA in humans and chimpanzees. Mol Biol Evol 10:512526

Vigilant L (1990) Control region sequences from African populations and the evolution of human mitochondrial DNA. $\mathrm{PhD}$ thesis, University of California, Berkeley

Vigilant L, Stoneking M, Harpending H, Hawkes K, Wilson AC (1991) African populations and the evolution of human mitochondrial DNA. Science 253:1503-1507

Wakeley J (1993) Substitution rate variation among sites in hypervariable region 1 of human mitochondrial DNA. J Mol Evol 37:613-623

Ward RH, Frazier BL, Dew-Jager K, Pääbo S (1991) Extensive mitochondrial diversity within a single Amerindian tribe. Proc Natl Acad Sci USA 88:8720-8724

Watson E, Bauer K, Aman R, Weiss G, von Haeseler A, Pääbo $S$ (1996) mtDNA sequence diversity in Africa. Am J Hum Genet 59:437-444

Address for correspondence and reprints: Prof. Dr. Hans-Jürgen Bandelt, Mathematisches Seminar, Universität Hamburg, Bundesstraße 55, D-20146 Hamburg, Germany.

(C) 1997 by The American Society of Human Genetics. All rights reserved. 0002-9297/97/6104-0029\$02.00

Am. J. Hum. Genet. 61:983, 1997

\section{Reply to Bandelt and Forster}

To the Editor:

It is well known (and is clearly stated in our article [Watson et al. 1996]) that patterns in mismatch distribu- tions can be influenced by many evolutionary scenarios other than population growth. In our study, we therefore applied two other approaches to the analysis of demographic history, a graphical method developed by Nee et al. (1995) and a statistical test developed by Tajima (1989). The results of both approaches were compatible with the hypothesis that the food-producing populations have expanded their size, whereas the other populations have not.

Concerning other issues discussed by Bandelt and Forster, we refer the reader to our original article (Watson et al. 1996), which we believe clarifies all relevant points.

GUNTER WeIsS, ARNDT vON HAESELER, AND SVANTE PÄÄBO

Institute of Zoology

University of Munich

Munich

\section{References}

Nee S, Holmes EC, Rambaut A, Harvey PH (1995) Inferring population history from molecular phylogenies. Phil Trans $R$ Soc Lond B 349:25-31

Tajima F (1989) The effect of change in population size on DNA polymorphism. Genetics 123:597-601

Watson E, Bauer K, Aman R, Weiss G, von Haeseler A, Pääbo $S$ (1996) mtDNA sequence diversity in Africa. Am J Hum Genet 59:437-444

Address for correspondence and reprints: Dr. Svante Pääbo, Institute of Zoology, University of Munich, Luisenstrasse 14, P.O. Box 202136, D-80021 Munich, Germany. E-mail: paabo@zi.biologie.uni-muenchen.de (1) 1997 by The American Society of Human Genetics. All rights reserved. 0002-9297/97/6104-0030\$02.00

Am. J. Hum. Genet. 61:983-986, 1997

\section{mtDNA Mutation Rates-No Need to Panic}

To the Editor:

Readers of the recent paper by Howell et al. (1996) might be forgiven for thinking that, after all the controversy surrounding the reconstruction of the original mitochondrial gene trees (e.g., see Maddison 1991; Templeton 1993), the field was once again in difficulties because of $(a)$ a serious underestimation of the mutation rate by a factor of almost nine and $(b)$ the resulting misdating of past divergences. We believe that such an interpretation would be unduly pessimistic.

Conventional approaches have calibrated the mutation rate by reference to the divergence between humans and chimpanzees. For the phylogenetically informative first hypervariable segment of the control region (HVSI), 
the divergence rate (twice the substitution rate) obtained is $\sim 30 \% /$ million years, or 1 transition $/ 10,000$ years, across this segment (Ward et al. 1991). In contrast, Howell et al. (1996) estimated the rate on the basis of the appearance of two new germ-line control-region mutations in a pedigree of 45 individuals segregating for Leber hereditary optic neuropathy (caused by a mutation at np 14484 in the NADH-dehydrogenase-6 gene). The rate that they obtained by this approach was $260 \% /$ million years - that is, almost nine times faster than the conventional rate. Since this rate is a potentially unbiased estimate of the rate of appearance of mutations, it might seem, at face value, that the conventional rate is a massively biased underestimation; however, this is not the case.

Leaving aside the issues of potential reporting biassince null studies would be unlikely to be publishedand of whether it is appropriate to extrapolate, to the general case, from a pedigree segregating for a mutant mitochondrial phenotype, there is one clear point that explains the discrepancy. The two new mutations are in the second hypervariable segment (HVSII), which is already known to have a higher heterogeneity of rates than is found in HVSI (Aris-Brosou and Excoffier 1996); however, it is HVSI that has been used in the large majority of anthropological studies-for example, to investigate the colonization of the Americas (e.g., see Ward et al. 1991, 1993; Shields et al. 1993; Forster et al. 1996), the Pacific (e.g., see Melton et al. 1995; Redd et al. 1995; Sykes et al. 1995) and Europe (e.g., see Bertranpetit et al. 1995; Francalacci et al. 1996; Richards et al. 1996). Howell et al. (1996) detected no new mutations in HVSI. Moreover, the two HVSII positions are among the fastest-evolving positions in the control region, as determined by phylogenetic analysis (Torroni et al. 1996). Therefore, the extrapolation of the fast mutation rate to HVSI alone will lead to an overestimation. In fact, even considered as an average rate for HVSI and HVSII, it is likely to be too fast, since it is not guaranteed that the observed heteroplasmy will resolve in favor of the mutant types in any female. It has been argued (Pääbo 1996; von Haeseler et al. 1996) that fast sites such as these will predominate among recent coalescences and be underestimated in more ancient ones, so that the faster rate (which they call the "pedigree" rate) may be more appropriate to a timescale of hundreds or thousands of years, whereas the slower rate (which they call the "phylogenetic" rate) may be suitable for a timescale of hundreds of thousands or millions of years. With respect to the phylogenetic rate, a timescale of millions of years is unrealistic, since many positions in the control region would have been saturated with transitions over this timescalewhich is the reason why transversional, rather than transitional, divergence is used to estimate the phyloge- netic rate (Ward et al. 1991). A timescale of roughly the past 150,000 years would seem to be reasonable for the application of this rate, since this was the range in which it was calibrated (by use of the transitiontransversion ratio in modern human populations).

The status of the pedigree rate is less clear-cut. On the basis of a parsimony analysis (Hasegawa et al. 1993), it has been estimated that $\sim 1 / 10$ positions in HVSI mutate $\geqslant 3$ times the average rate and that several mutate $\geqslant 10$ times the rate. Is there any evidence that these sites are sufficient to elevate the pedigree rate significantly over the phylogenetic rate in this segment? We observed seven maternally unrelated individuals who were heteroplasmic for HVSI in a British sample of 473 individuals. Inferring typical fixation times from observations of the segregation of alleles in heteroplasmic pedigrees, we have estimated a pedigree divergence rate in the range of 1 transition/2,000-20,000 years (Bendall et al. 1996). This is indeed skewed toward a faster rate than the conventional (phylogenetic) rate of $1 / 10,000$ years, and, as we might expect, if we compare this result with the analysis of fast sites by Hasegawa et al. (1993), we note that all seven sites have mutated more often than the average and that two of them are among the three that mutated most often; those two sites were also shown to be fast by Wakeley (1993), Forster et al. (1996), and Torroni et al. (1996).

Given that the pedigree rate may be measurably higher than the phylogenetic rate, one would expect a monotonic decline from one to the other as the time depth increases. The problem would lie in deciding on the rate that is appropriate to any particular data set. How can we assess which sequences coalesce hundreds or thousands of years ago, without knowing a priori what the rate is? In order to test empirically whether the pedigree rate is more appropriate at evolutionarily recent time depths, we can compare the performance of the pedigree rate against the conventional phylogenetic rate in the case of the settlement of the Cook Islands in central Polynesia. The settlement of Polynesia is a special case of population expansion, since it is very recent (occurring $\sim 1,000-3,000$ years ago) and well-dated archaeologically. Furthermore, it is characterized by the spread of a particular mtDNA lineage group defined by a 9-bp deletion and a distinctive control-region-sequence motif. This lineage group must have arisen prior to the settlement of Polynesia, since it is ubiquitous throughout the region, and indeed phylogeographic analysis of lineages from Southeast Asia confirm this (Melton et al. 1995; Redd et al. 1995; Sykes et al. 1995). Applying the conventional mutation rate to data from the Cook Islands (Sykes et al. 1995) yields a coalescence time of 1,100 \pm 800 years ago-in agreement with the archaeological dates of 900-1,300 years ago for the first settlements (Bellwood 1978). Applying Howell et al.'s pedigree rate 
Table 1

Comparison of Archaeological Dates for Onset of Farming, in Four Populations, with mtDNA Dates Derived from Pedigree Rate

\begin{tabular}{lcccc}
\hline & Archaeological Date & & \\
Population (Sample Size) & Rogers's Estimator of $\tau^{\mathrm{a}}$ & $\begin{array}{c}\text { Onset of Farming } \\
\text { (years ago) }\end{array}$ & $\begin{array}{c}\tau \text { Derived from Farming } \\
\text { Date and Pedigree Rate }\end{array}$ & $\begin{array}{c}\text { Central 95\% of Simulated } \\
\tau \text { Values }\end{array}$ \\
\hline European $(753)^{\mathrm{c}}$ & 2.60 & $\sim 8,000^{\mathrm{g}}$ & 5.76 & $5.2-8.0$ \\
${\text { Havik Indian }(46)^{\mathrm{d}}}_{\text {Japanese }(61)^{\mathrm{e}}}$ & 4.22 & $\sim 4,000^{\mathrm{h}}$ & 2.88 & $2.0-5.4$ \\
${\text { Somali }(27)^{\mathrm{f}}}^{4.93}$ & $\sim 2,400^{\mathrm{i}}$ & 1.73 & $1.1-4.0$ \\
\hline
\end{tabular}

${ }^{a}$ From Rogers (1995)

${ }^{b}$ From a model of sudden expansion (Rogers and Harpending 1992), with $\tau$ determined from the date of the archaeological appearance of farming and the pedigree rate and with the mutation-drift parameters, before and after the expansion, being 1.8 and 1,800, respectively, a coalescent algorithm was used to generate 1,000 data sets/population, for each of which Rogers's (1995) estimator of $\tau$ was evaluated. The range of $\tau$ 's quoted is that between the $2.5 \%$-ile and the $97.5 \%$-ile. The mutation-drift parameter before expansion was chosen small enough so that the majority of generated data sets had a unimodal pairwise distribution as required by the hypothesis of Pääbo (1996), even though this may imply an implausibly small preexpansion population size.

' SOURCE. - Richards et al. (1996).

${ }^{d}$ SOURCE. - Mountain et al. (1995).

' SOURCE. - Horai and Hayasaka (1990).

${ }^{f}$ SOURCE. - Watson et al. (1996).

g SOURCE. - Whittle (1985).

h SOURCE. - Meadow (1996).

i SOURCE. - Imamura (1996).

i SOURCE. - Phillipson (1993).

to the same data yields a coalescence time $<150$ years ago. Such a date could be explained only by very recent population bottlenecks, which would be very difficult to reconcile with the observed uniformity of lineages across Polynesia. This observation strongly suggests that the phylogenetic rate is appropriate to events at least as recent as 1,000 years ago.

This issue is relevant to population expansions elsewhere. Is it possible that the bell-shaped distributions of pairwise differences between sequences and the starlike phylogenies seen in other parts of the world could have been generated by the onset of food production, within the past 10,000 years? This is the suggestion in a recent application (Pääbo 1996; von Haeseler et al. 1996) of the pedigree rate to existing data sets from Europe (Sajantila et al. 1995; Sajantila and Pääbo 1995), Asia (Mountain et al. 1995), and Africa (Watson et al. 1996). This suggestion runs counter to the prevailing view that the major expansions that left their signatures in mtDNA sequence patterns took place during the Pleistocene, starting $\sim 60,000-70,000$ years ago (Rogers and Harpending 1992; Harpending et al. 1993; Sherry et al. 1994; Rogers 1995).

We can test whether expansion times, $\tau$, in the various populations, as determined on the basis of the estimator of Rogers (1995), are consistent with the first appearance, in the archaeological record, of agriculture (table 1). First, note that the order of the expansion times does not seem to correlate at all well with that of the archaeological dates. Second, if we test the hypothesis that the unimodal pairwise distribution combined with the pedigree rate indicates a farming expansion, by simulating many data sets and evaluating the estimator of $\tau$ for each, the observed values of $\tau$ lie outside the central $95 \%$ of simulated values for three of the four populations (table 1); hence the hypothesis must be rejected. On the other hand, we can apply the usual phylogenetic rate to the $\tau$ values to obtain expansion times. Although, in the absence of any phylogenetic analysis, this methodology is crude, the resulting times seem to fit well with the notion of a Pleistocene wave of expansion originating in Africa 60,000-70,000 ago, which spread into and across Asia and then into Europe. We conclude that the conventional phylogenetic rate is adequate for time depths of $\geqslant 1,000$ years and that, contrary to the inference of Howell et al. (1996), there is no need for drastic revisions of coalescence or expansion times.

VinCENT A. MaCaUlay, ${ }^{1}$ MaRTin B. Richards, ${ }^{1}$ PeTER Forster, ${ }^{2}$ KATE E. Bendall, ${ }^{1}$ Elizabeth WATSON, ${ }^{4}$ BRYAN SYKES, ${ }^{1}$ AND HANS-JURGEN BANDELT $^{3}$

${ }^{1}$ Institute of Molecular Medicine, University of Oxford, Oxford; ${ }^{2}$ Heinrich-Pette-Institut and ${ }^{3}$ Mathematisches Seminar, Universität Hamburg, Hamburg; and ${ }^{4}$ School of Biological Sciences, Massey University, Palmerston North, New Zealand

\section{Acknowledgments}

We are grateful to Terry Melton, Antonio Torroni, and Peter Donnelly for critical advice. This work is supported by The Wellcome Trust. 


\section{References}

Aris-Brosou S, Excoffier L (1996) The impact of population expansion and mutation rate heterogeneity on DNA sequence polymorphism. Mol Biol Evol 13:494-504

Bellwood P (1978) The Polynesians: prehistory of an island people. Thames \& Hudson, London

Bendall KE, Macaulay VA, Baker JR, Sykes BC (1996) Heteroplasmic point mutations in the human mtDNA control region. Am J Hum Genet 59:1276-1287

Bertranpetit J, Sala J, Calafell F, Underhill PA, Moral P, Comas D (1995) Human mitochondrial DNA variation and the origin of Basques. Ann Hum Genet 59:63-81

Forster P, Harding R, Torroni A, Bandelt H-J (1996) Origin and evolution of Native American mtDNA variation: a reappraisal. Am J Hum Genet 59:935-945

Francalacci P, Bertranpetit J, Calafell F, Underhill PA (1996) Sequence diversity of the control region of mitochondrial DNA in Tuscany and its implications for the peopling of Europe. Am J Phys Anthropol 100:443-460

Harpending HC, Sherry ST, Rogers AR, Stoneking M (1993) The genetic structure of ancient human populations. Curr Anthropol 34:483-496

Hasegawa M, Di Rienzo A, Kocher TD, Wilson AC (1993) Toward a more accurate time scale for the human mitochondrial DNA tree. J Mol Evol 37:347-354

Horai S, Hayasaka K (1990) Intraspecific nucleotide sequence differences in the major noncoding region of human mitochondrial DNA. Am J Hum Genet 46:828-842

Howell N, Kubacka I, Mackey DA (1996) How rapidly does the human mitochondrial genome evolve? Am J Hum Genet 59:501-509

Imamura K (1996) Jomon and Yayoi: the transition to agriculture in Japanese prehistory. In: Harris DR (ed) The origins and spread of agriculture and pastoralism in Eurasia. UCL Press, London, pp 442-464

Maddison D (1991) African origin of human mitochondrial DNA reexamined. Syst Zool 40:355-363

Meadow RH (1996) The origins and spread of agriculture and pastoralism in northwestern South Asia. In: Harris DR (ed) The origins and spread of agriculture and pastoralism in Eurasia. UCL Press, London, pp 390-412

Melton T, Peterson R, Redd AJ, Saha N, Sofro ASM, Martinson J, Stoneking M (1995) Polynesian genetic affinities with Southeast Asian populations as identified by mtDNA analysis. Am J Hum Genet 57:403-414

Mountain JL, Hebert JM, Bhattacharyya S, Underhill PA, Ottolenghi C, Gadgil M, Cavalli-Sforza LL (1995) Demographic history of India and mtDNA-sequence diversity. Am J Hum Genet 56:979-992

Pääbo S (1996) Mutational hot spots in the mitochondrial microcosm. Am J Hum Genet 59:493-496

Phillipson DW (1993) African archaeology. Cambridge University Press, Cambridge

Redd AJ, Takezaki N, Sherry ST, McGarvey ST, Sofro ASM, Stoneking M (1995) Evolutionary history of the COIV tRNA(Lys) intergenic 9-base-pair deletion in human mitochondrial DNAs from the Pacific. Mol Biol Evol 12:604615

Richards M, Côrte-Real H, Forster P, Macaulay V, Wilkinson-
Herbots H, Demaine A, Papiha S, et al (1996) Paleolithic and Neolithic lineages in the European mitochondrial gene pool. Am J Hum Genet 59:185-203

Rogers AR (1995) Genetic evidence for a pleistocene population explosion. Evolution 49:608-615

Rogers AR, Harpending H (1992) Population growth makes waves in the distribution of pairwise genetic differences. Mol Biol Evol 9:552-569

Sajantila A, Lahermo P, Anttinen T, Lukka M, Sistonen P, Savontaus ML, Aula P, et al (1995) Genes and languages in Europe: an analysis of mitochondrial lineages. Genome Res 5:42-52

Sajantila A, Pääbo S (1995) Language replacement in Scandinavia. Nat Genet 11:359-360

Sherry ST, Rogers AR, Harpending H, Soodyall H, Jenkins T, Stoneking M (1994) Mismatch distributions of mtDNA reveal recent human population expansions. Hum Biol 66: 761-775

Shields GF, Schmiechen AM, Frazier BL, Redd A, Voevoda MI, Reed JK, Ward RH (1993) mtDNA sequences suggest a recent evolutionary divergence for Beringian and northern North American populations. Am J Hum Genet 53:549562

Sykes B, Leiboff A, Low-Beer J, Tetzner S, Richards M (1995) The origins of the Polynesians: an interpretation from mitochondrial lineage analysis. Am J Hum Genet 57:1463-1475

Templeton AR (1993) The 'Eve' hypothesis: a genetic critique and reanalysis. Am Anthropol 95:51-72

Torroni A, Huoponen K, Francalacci P, Petrozzi M, Morelli L, Scozzari R, Obinu D, et al (1996) Classification of European mtDNAs from an analysis of three European populations. Genetics 144:1835-1850

von Haeseler A, Sajantila A, Pääbo S (1996) The genetical archaeology of the human genome. Nat Genet 14:135-140

Wakeley J (1993) Substitution rate variation among sites in hypervariable region 1 of human mitochondrial DNA. J Mol Evol 37:613-623

Ward RH, Frazier BL, Dew-Jager K, Pääbo S (1991) Extensive mitochondrial diversity within a single Amerindian tribe. Proc Natl Acad Sci USA 88:8720-8724

Ward RH, Redd A, Valencia D, Frazier B, Pääbo S (1993) Genetic and linguistic differentiation in the Americas. Proc Natl Acad Sci USA 90:10663-10667

Watson E, Bauer K, Aman R, Weiss G, von Haeseler A, Pääbo $\mathrm{S}$ (1996) MtDNA sequence diversity in Africa. Am J Hum Genet 59:437-444

Whittle A (1985) Neolithic Europe: a survey. Cambridge University Press, Cambridge

Address for correspondence and reprints: Dr. Vincent Macaulay, Institute of Molecular Medicine, John Radcliffe Hospital, Headley Way, Headington, Oxford, OX3 9DS, United Kingdom. E-mail: vincent.macaulay@cellsci.ox.ac.uk () 1997 by The American Society of Human Genetics. All rights reserved. 0002-9297/97/6104-0031\$02.00

Am. J. Hum. Genet. 61:986-990, 1997

\section{Reply to Macauley et al.}

To the Editor:

We wish to respond to the comments of Macauley et al. (1997) that address our recent report on the rate of 